\title{
DESIGN, MANUFACTURING AND TESTING KINETIC ADSORPTION TEST RIG
}

\author{
Abrar Ridwan, Nasruddin, Awaludin Martin, Arfie I. Firmansyah \\ Laboratory of Refrigeration and Air Conditioning, Mechanical Engineering Department, \\ Faculty of Engineering-University of Indonesia \\ e-mail: awaludin.martin@ui.edu
}

\begin{abstract}
Adsorption on a solid adsorbent is the fundamental processes in the field of separation processes, purification of gases, adsorption cooling, advanced adsorption cooling, and extensive work on hydrogen storage. The understanding of the thermodynamic properties of adsorbent plus adsorbate system is important to analyze. Information concerning the relevant adsorption equilibrium and characterized of adsorbent is generally an essential requirement for the analysis and design of an adsorption separation process. For practical application, the adsorption equilibrium must be known over a broad range of operation temperatures. Also, the isotherms of pure species are fundamental information for dynamic simulation of adsorbers. The main objective of this research is to design kinetic adsorption test rig to investigate the capacity and rate of adsorption on adsorbent and adsorbate pair's. The result of design kinetic adsorption test rig including dimensions of vapor vessel (pressure vessel) and measuring cell. The volume of vapour vessel is $1000 \mathrm{ml}$ and measuring cell is $100 \mathrm{ml}$. Kinetic adsorption test rig was manufactured to investigate capacity and rate of adsorption up to 40 bar.
\end{abstract}

Keywords: Kinetic adsorption test rig, capacity and rate of adsorption.

\section{INTRODUCTION}

Adsorption on a solid adsorbent is the fundamental processes in the field of separation processes, purification of gases, and adsorption cooling. The understanding of the thermodynamic property fields of adsorbent plus adsorbate system is important because it enables the adsorption processes to be analyzed.(Saha, B.B., et al, 2006).

Information concerning the relevant adsorption equilibrium and characterized of adsorbent is generally an essential requirement for the analysis and design of an adsorption separation process. For practical application, the adsorption equilibrium must be known over a broad range of operation temperatures (Lee, Jong-Seok, et al, 2002)

At least, there are two methods two know the adsorption equilibrium, first is direct method (gravimetric method) and secondly is indirect method (volumetric method).

The main objective of this research is to design and manufacturing kinetic adsorption test rig to investigate the adsorption equilibrium such as capacity and rate of adsorption with indirect method (volumetric method). The data will be the basic data for analysis and design of an adsorption process.

\section{THERMODYNAMICAL ANALYSIS}

An adsorbate mass balance on the measuring cell of the sorption kinetic test rig yield (Dawoud dan Aristov, 2003):
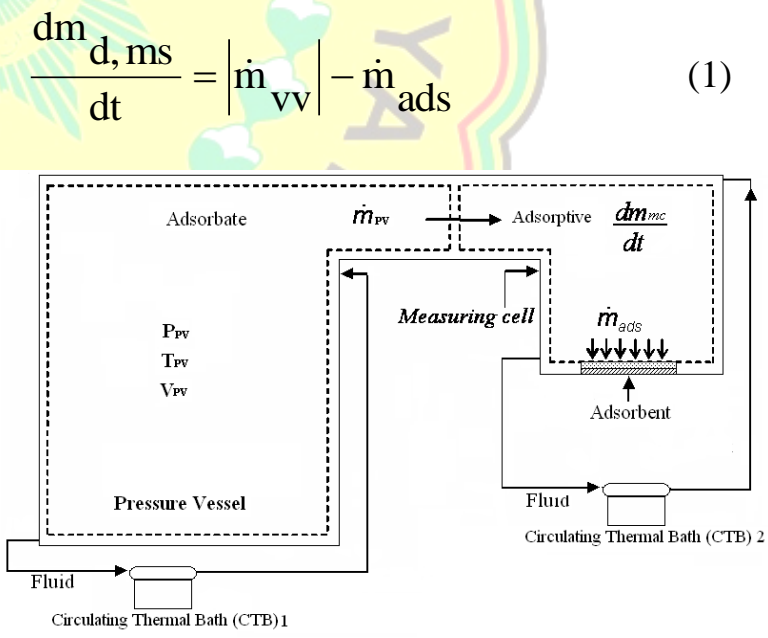

Figure 1. Scheme of kinetic adsorption test rig

Where:

$\begin{array}{cl}\frac{\mathrm{dm}_{\mathrm{d}, \mathrm{ms}}}{\mathrm{dt}}: & \text { adsorbate mass flow rate in } \\ & \text { measuring cell }(\mathrm{kg} / \mathrm{s})\end{array}$ 
$\left|\dot{\mathrm{m}}_{\mathrm{Vv}}\right|$ : adsorbate mass flow rate in vapour vessel $(\mathrm{kg} / \mathrm{s})$

$\dot{m}_{\text {ads }}$ : mass flow rate of adsorbate on adsorbent $(\mathrm{kg} / \mathrm{s})$

Assuming an ideal gas behavior for the adsorbate during the whole sorption process, both the rate of adsorbate flow from the vapor vessel to the measuring cell and the time rate of variation of the mass of the vapor phase in the measuring cell can be obtained according to the following equations (2) and (3).

$$
\begin{aligned}
& \left|\dot{\mathrm{m}}_{\mathrm{VV}}\right|=\left|\frac{\Delta \mathrm{m}_{\mathrm{VV}}}{\Delta \mathrm{t}}\right|=\frac{\mathrm{m}_{\mathrm{VV}}(\mathrm{t})-\mathrm{m}_{\mathrm{VV}}(\mathrm{t}+\Delta \mathrm{t})}{\Delta \mathrm{t}} \\
& =\frac{\left(p_{V V}(t)-p_{V V}(t+\Delta t)\right) \cdot V_{V V}}{R_{V V} \cdot T_{V V} \cdot \Delta t} \\
& \frac{\mathrm{dm}_{\mathrm{d}, \mathrm{ms}}}{\mathrm{dt}}=\frac{\left(\mathrm{m}_{\mathrm{d}, \mathrm{ms}}(\mathrm{t}+\Delta \mathrm{t})-\mathrm{m}_{\mathrm{d}, \mathrm{ms}}(\mathrm{t})\right.}{\Delta \mathrm{t}} \\
& =\frac{\left(\mathrm{p}_{\mathrm{ms}}(\mathrm{t}+\Delta \mathrm{t})-\mathrm{p}_{\mathrm{ms}}(\mathrm{t})\right) \cdot \mathrm{V}_{\mathrm{ms}}}{\mathrm{R}_{\mathrm{d}} \cdot \mathrm{T}_{\mathrm{ms}} \cdot \Delta \mathrm{t}}
\end{aligned}
$$

By substitution equations (2) and (3) to equation (1) can be obtained:

$$
\begin{aligned}
\dot{\mathrm{m}}_{\mathrm{ads}}= & \frac{\Delta \mathrm{m}_{\mathrm{ads}}(\mathrm{t})}{\Delta \mathrm{t}}=\frac{\left(\mathrm{p}_{\mathrm{vv}}(\mathrm{t})-\mathrm{p}_{\mathrm{vV}}(\mathrm{t}+\Delta \mathrm{t})\right) \cdot \mathrm{V}_{\mathrm{vV}}}{\mathrm{R}_{\mathrm{vV}} \cdot \mathrm{T}_{\mathrm{vv}} \cdot \Delta \mathrm{t}} \\
& -\frac{\left(\mathrm{p}_{\mathrm{ms}}(\mathrm{t}+\Delta \mathrm{t})-\mathrm{p}_{\mathrm{ms}}(\mathrm{t})\right) \cdot \mathrm{v}_{\mathrm{ms}}}{\mathrm{R}_{\mathrm{d}} \cdot \mathrm{T}_{\mathrm{ms}} \cdot \Delta \mathrm{t}}
\end{aligned}
$$

Knowing the mass of the dry adsorbent sample $\mathrm{m}_{\mathrm{s} \text {,dry }}$ as well as the starting adsorbate loading $\mathrm{x}_{0}$, the time variation of the adsorbate loading can be calculated due to equation (5):

$$
\mathrm{x}=\mathrm{x}_{0}+\sum_{\mathrm{t}=0}^{\mathrm{t}} \frac{\Delta \mathrm{m}_{\mathrm{ads}}}{\mathrm{m}_{\mathrm{s}, \text { dry }}}
$$

In order to compare the results of measuring the sorption kinetics under different operating conditions, it is reasonable to represent the time variation of the adsorbate loading in a dimensionless form. This may occur by defining the dimensionless differential adsorbate loading $\chi$ as the ratio between the instantaneous differential adsorbate loading to the maximum differential adsorbate loading achievable at each operating condition of the sorption process on the sorbent sample.

$$
\chi(t)=\frac{x(t)-x_{0}}{x_{\infty}-x_{0}}
$$

\section{METHODE OF DESIGN}

Kinetic adsorption test rig consist of pressure vessel, measuring cell, vacuum pump, gas vessel, pressure transmitter, thermocouple Type $\mathrm{K}$, and circulating thermal bath. Design of kinetic adsorption test rig only for pressure vessel and measuring cell.

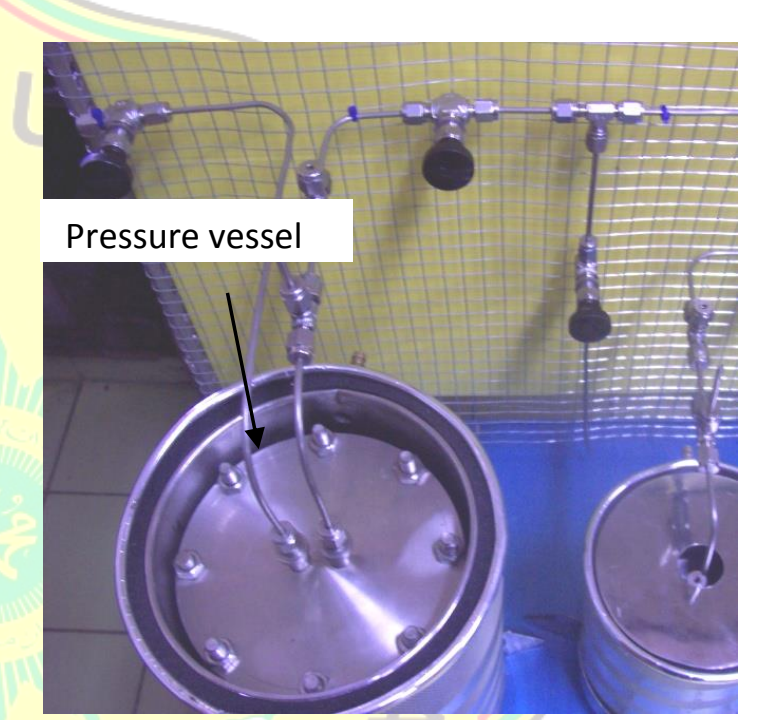

Figure 2. Pressure Vessel

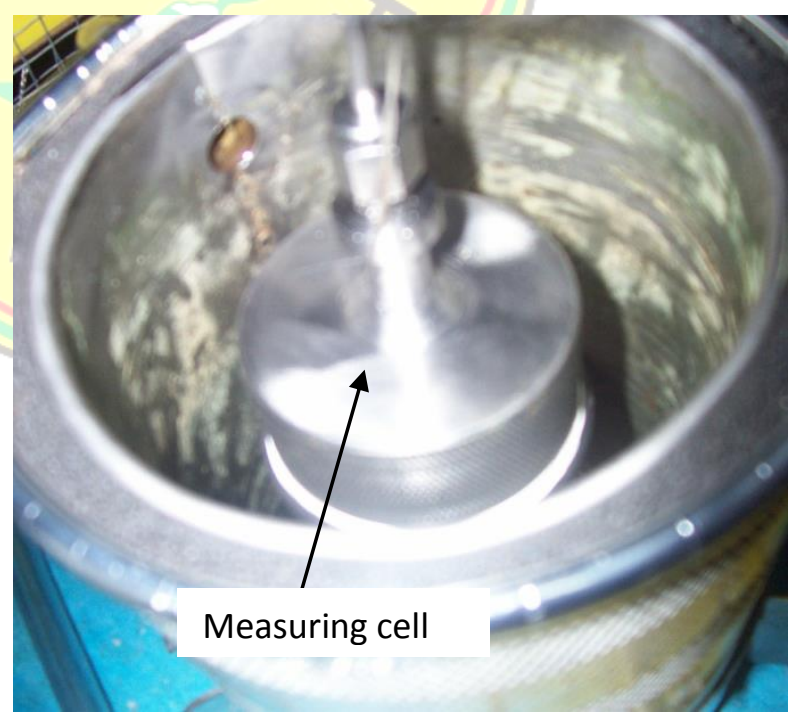

Figure 3. Measuring Cell

\section{Measurement}

The Adsorption experiments were based on the static volumetric method. In this method, the 
maximum capacity and adsorption rate of adsorbate on adsorbent were determined by appropriate pressure and temperature measurement.

The system pressure was measured by an absolute presure transmitters (DRUCK, PTX 1400) ), the pressure range are $0-40$ bar and its reading uncertainty is $\pm 0.15 \%$ within the useable measurement range with a high accuracy signal conditioner (ADAM, type 4018).

The system temperature was measured by Thermocouple type K

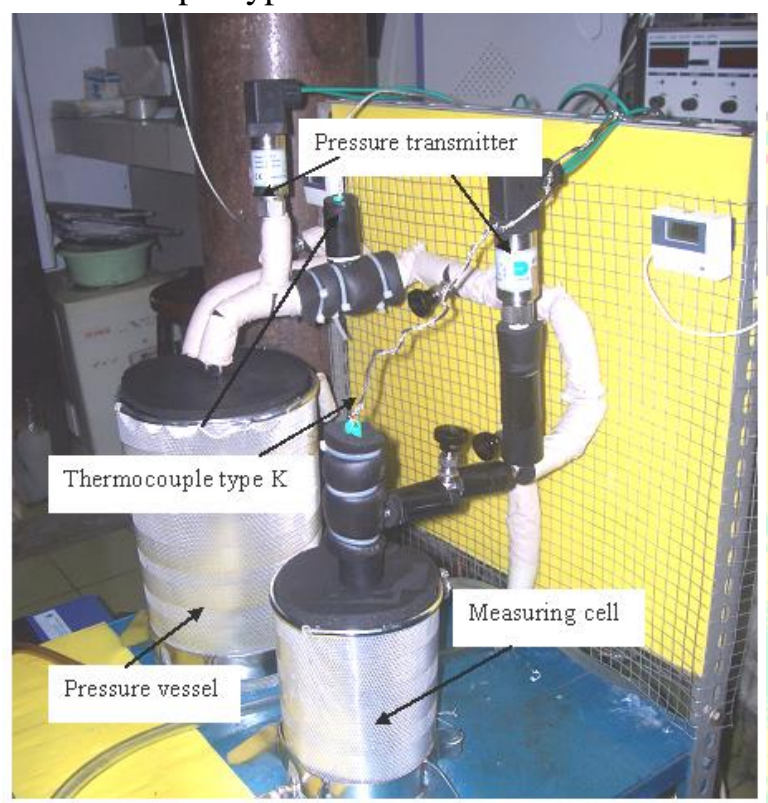

Figure 4. Pressure transmitter and thermocouple type $\mathrm{K}$

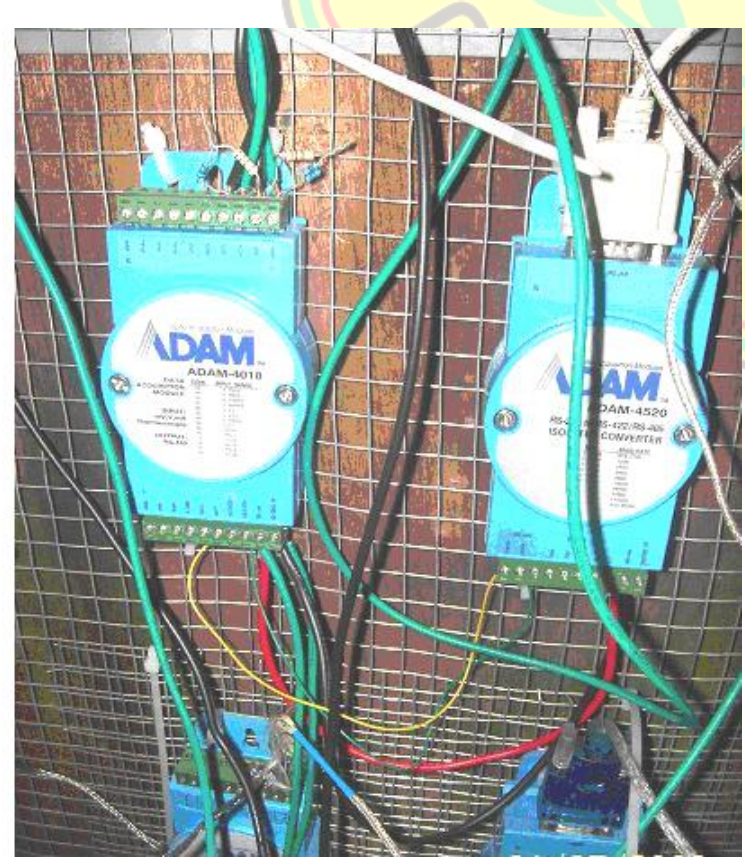

Figure 5. Data acquisition modules
During the experiment, the temperature in pressure vessel and measuring cell were maintained by circulating thermal bath and the temperature controllers of the circulating thermal bathes have an accuracy of $\pm 0.2^{\circ} \mathrm{C}$.

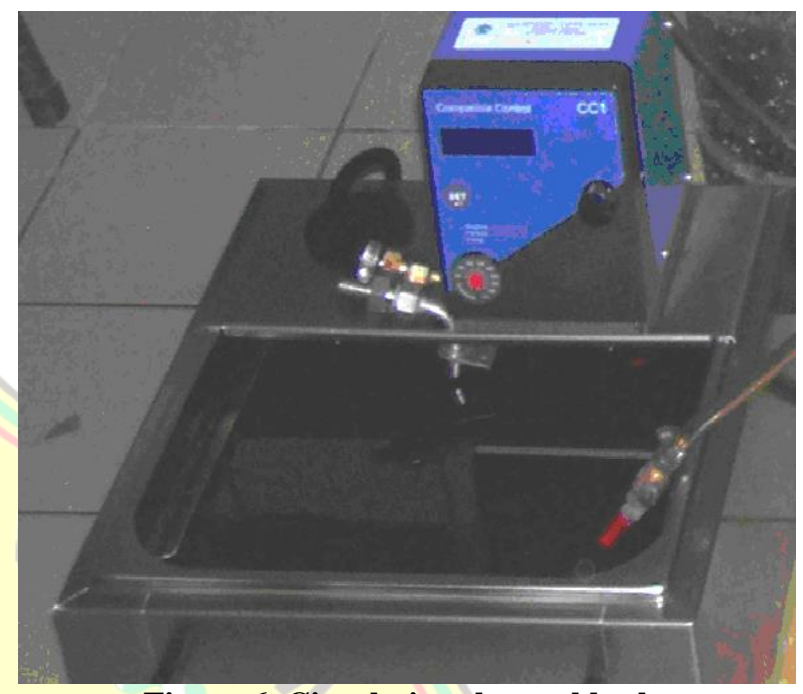

Figure 6. Circulating thermal bath

\section{EXPERIMENTAL PROCEDURE}

In order to activate the adsorbent sample, the measuring cell is heated to $150^{\circ} \mathrm{C}$ and evacuated, in the same time, for $1 \mathrm{~h}$ using a vacuum pump (degassing process). During this process, measuring cell is separated from pressure vessel and kinetic adsorption test rig system. After degassing process the measuring cell is cooled down to the required sorption temperature and measuring cell were connected with tubing to the kinetic adsorption test rig system.

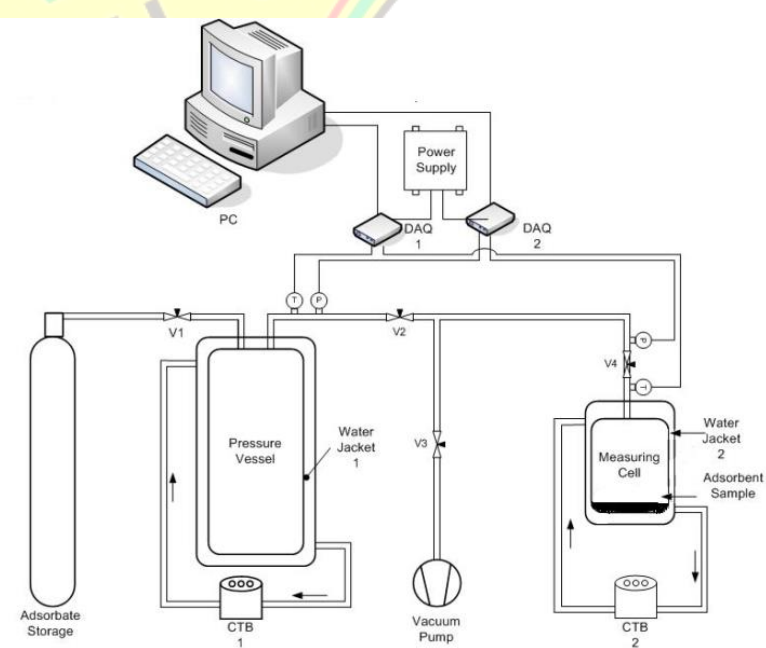

(a) 


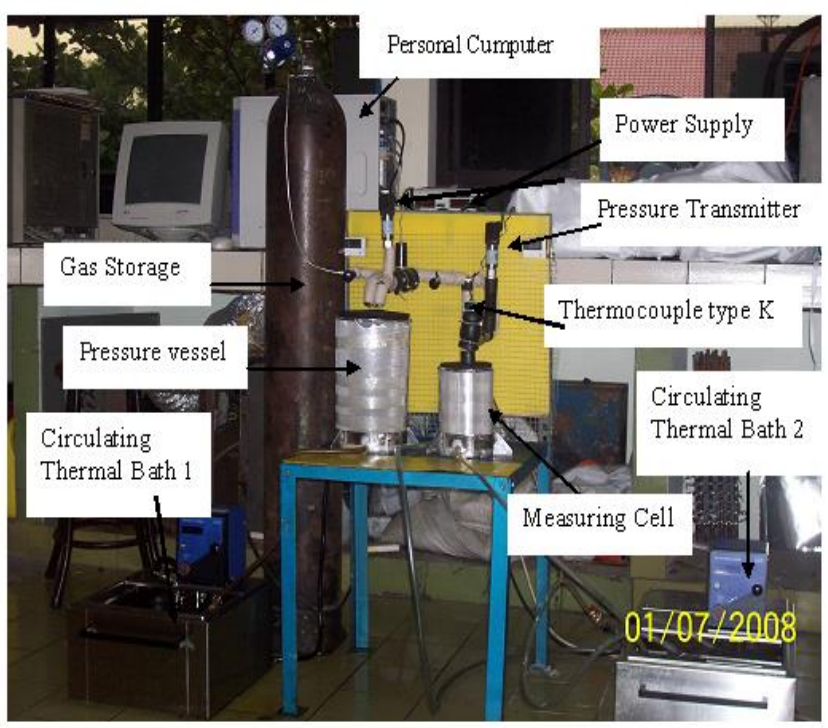

(b)

Figure 7. Schematic of kinetic adsorption test rig (a) picture of kinetic adsorption test rig (b).

The temperature of the pressure vessel is adjusted to the required sorption temperature, and then charged with adsorbat (gas) from the gas storage, up to the required starting pressure for the sorption process. The temperature of the connecting piping and valves has to be adjusted and controlled to the required sorption temperature.

The first sorption process starts when the valve V2 and V4 is opened (in figure 7a), resulting in decreasing the pressure in the pressure vessel for 30 minutes. During the first sorption process, the temperature of water in circulating thermal bath 2 was prepared to be $10^{\circ} \mathrm{C}$. The sorption process starts when the temperature of water in circulating thermal bath is $10^{\circ} \mathrm{C}$ and was flowed to water jacket of measuring cell.

The pressure variation, being measured using the two pressure transmitters P1\& P2 are used to determine the amount of the adsorbed gas on the adsorbent sample.

\section{Repeatibility of Kinetic Adsorption Test Rig}

Repeatibility was done to guarantee that kinetic adsorption test rig can result the capacity and rate of adsorption data in the same value on the same condition. Figure 9 describes $\mathrm{CO}_{2}$ adsorption on commercial activated carbon at presure equlibrium $1.5 \mathrm{bar}$ and at isothermal temperatur $30^{\circ} \mathrm{C}$. It can be seen from figure 9 , in general the path of the graph almost have the same value, the different of both of path causes dry sorbent mass of activated carbon is different.

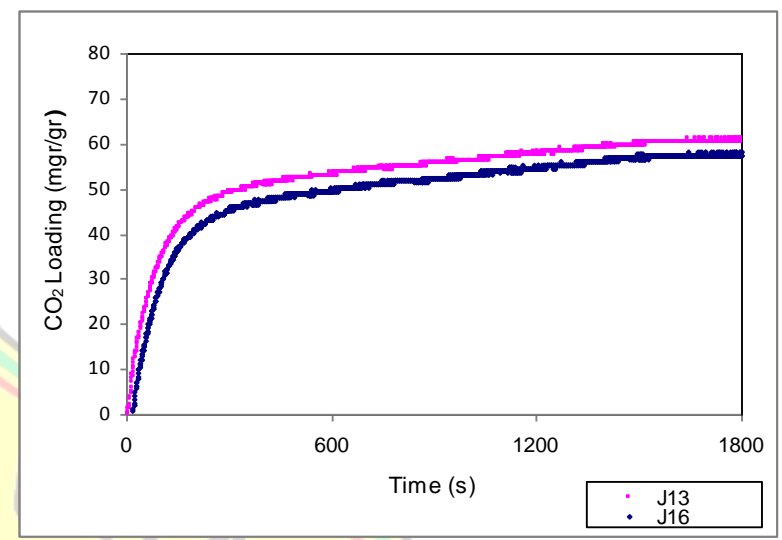

Figure 8. $\mathrm{CO}_{2}$ adsorption on commercial activated carbon

\section{CONCLUSION}

1. Kinetic adsorption test rig can be use for research in adsorption engineering to investigate capacity and rate of adsorption data

2. Kinetic adsorption test rig was manufactured to investigate capacity and rate of adsorption up to 40 bar

3. Pressure vessel and measuring cell were design for pressure up100 bar.

\section{ACKNOWLEDGMENT}

This research was supported by the Higher Education Directorate, National Education Department of Republic Indonesia, through Project Hibah Bersaing and Contract No. 239 AT/DRPM-UI/N14/2008 respectively.

\section{REFFERENCE}

Dawoud, Belal, Yuri Aristov, 2003, Experimental Study on The Kinetics of Water Vapor Sorption on Selective Water Sorbent, Silica Gel and Alumina Under Typical Operating Conditions of Sorption Heat Pumps, International Jounal of Heat and Mass Transfer, pp 273-281

Elyas, Anas, 2006, Experimentelle Untersuchung der Adsorptions- und Desorptionskinetik von Wasserdampf auf losen Pellets von 
SWS-1L unter den Betriebsbedingungen von Adsorptionswärmepumpen, Thesis, Rheinisch - Westfälische Technische Hochschule, Aachen

Jong-Seok Lee, Jong-Hwa Kim, Jin-Tae Kim, Jeong-Kwon Suh, Jung-Min Lee, and Chang-Ha Lee, 2002 Adsorption Equilibria of $\mathrm{CO} 2$ on Zeolite $13 \mathrm{X}$ and
Zeolite X/Activated Carbon Composite, J. Chem. Eng. Data 2002, 47, 1237-1242

Saha, B.B., Ibrahim I. El-Sharkawy, Anutosh Chakraborty, Shigeru Koyama, SeongHo, and Kim Choon Ng, 2006, Adsorption Rate of Ethanol on Activated Carbon Fiber, J. Chem. Eng. Data, 2006, 51, 1587-1592

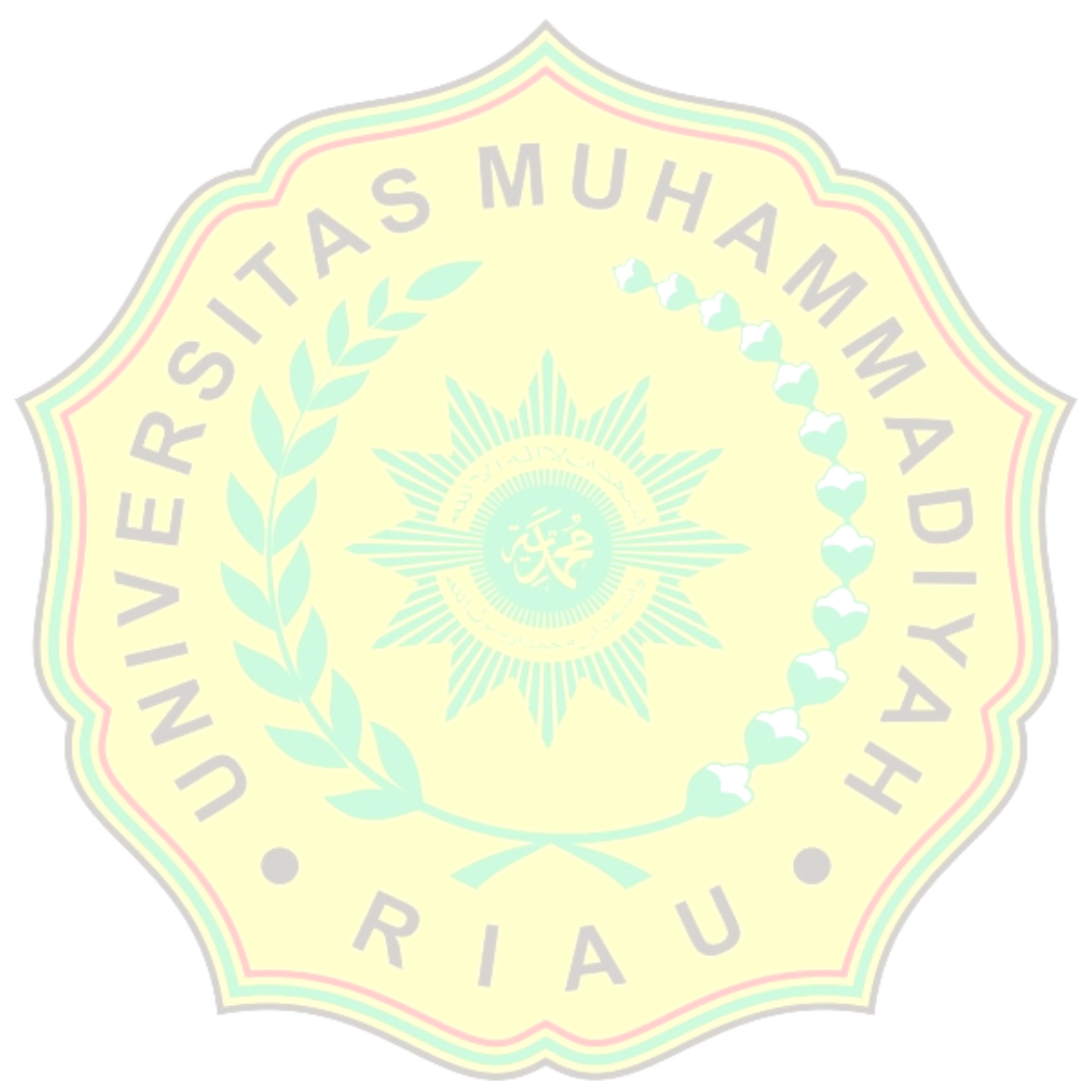

